\title{
Was Economic Growth Likely in Lower Canada?
}

\section{Vincent Geloso}

Texas Tech University

\section{Mathieu Bédard}

Montreal Economic Institute

\begin{abstract}
Generally, the historical literature presents the period from 1817 to 1851 in Lower Canada (the modern-day province of Quebec) as one of negative economic growth. In this paper, we question this narrative by pointing to the rise of free banking during the period, which supports a case for increases in per capita income. Using the equation of exchange, we propose that given the increase in the stock of money and the reduction in the general price level, the case for a fall in per capita income is tenuous. We present complementary evidence suggesting that growth was positive.
\end{abstract}

\section{JEL Codes: E31, N11, N21}

Keywords: economic growth, free banking, price level, private money

\section{Introduction}

One of the most contentious claims in Canadian economic history concerns the existence of an "agricultural crisis" in the early nineteenth century. The term is used with reference to a protracted period of poor economic performance in the predominantly rural economy of Britain's colony in Lower Canada (modern-day Quebec). The literature on the topic has divided itself into two broad camps: the traditionalists and the revisionists.

The traditionalists emphasize that cultural conservatism retarded innovation in farming practices. This, combined with population growth, poor access to foreign markets, and the depredations of the hessian fly, led to a prolonged crisis in the agricultural sector which, given the sector's importance in the economy, meant a decline in living standards. The revisionists, in contrast, point to positive indicators of growth and a reorganization of the economy away from the production of wheat and toward new products. In general, the revisionists point to modest growth in living standards. 
In this paper, we present evidence in favor of the revisionist position. We argue that, at the very least, growth ought to have been positive. We do so by using three tools.

The first relates to the literature on free banking. In the late 1810s, Lower Canada's banking sector emerged (Shortt [1900] 1986; Denison 1965) and represented a near, but not absolute, case of pure free banking (Smith 1936). The supply of private banknotes expanded rapidly, far outstripping population growth, while reserve ratios plummeted. The emergence and development of banks in Lower Canada, which would have meant greater access to debt and equity financing for businesses (Levine 1997; Rousseau and Sylla 2005), suggests the presence of positive economic growth. The paper notes that banks issued were not fiat money as we think of them today; rather, they were backed by the commercial loans of the banks that issued them. As such, the increasing supply of private bank notes implies growth in commercial bank lending (i.e., investments) (Lastrapes and Selgin 2012).

The second tool relates to the theoretical apparatus provided by the equation of exchange $(M V=P Y)$. While the banks were increasing the supply of redeemable notes, the price level in Lower Canada was following a downward trend. Under the equation of exchange, unless velocity ( $V$ ) falls rapidly, a rising (private) money supply $(M)$ and a falling price level $(P)$ imply that there must have been an increase in output $(Y)$. The evolution of $M$ and $P$ in Lower Canada undermine the case that there was negative economic growth.

The third tool relates to other pieces of evidence (imports per capita, demographic evidence, and urbanization rates) that support the contention of positive economic growth.

All of these tools point to positive economic growth. We do not try to assert that it was robust growth-merely that the case for negative economic growth is dubious at best.

In section 2, we briefly review the debate over the "agricultural crisis." In section 3, we highlight the features of the free banking system in Lower Canada and how, in combination with the equation of exchange, it may resolve the longstanding dispute between revisionists and traditionalists. In section 4 , we present the evidence regarding macroeconomic developments, imports, mortality rates, and urbanization that supports the revisionist position. Section 5 provides a conclusion and implications for other researchers. 


\section{Agricultural Crisis}

In general, Canadian economic history in the early nineteenth century is perceived as disappointing (Buckley 1958). More precisely, Lower Canada (the modern-day, French-speaking province of Quebec) and the Atlantic colonies were considered the laggards (Ouellet 1966, 1972, 1980; Paquet and Wallot 2007; Gwyn 1998) while Upper Canada (modern-day Ontario) was perceived as doing better (McCalla 1985, 1993, 2008; Lewis and Urquhart 1999).

The attention has mostly centered on Lower Canada (Russell 2012), which the traditionalists argue experienced a "prolonged agricultural crisis" that started around 1800 and lasted until the late 1840s. This thesis has been most notably advanced by Maurice Séguin (1970), Fernand Ouellet (1966, 1972, 1980; Ouellet and Hamelin 1962), John McCallum (1980), and Louise Dechêne (1986) and has received some recent cliometric support from Altman (1998). ${ }^{1}$ Their core argument is that there was a series of structural problems and exogenous shocks. The underlying structural problems resulted from the poor farming skills of the French-Canadian population of Lower Canada (the majority of the population). Supposedly, they clung to wheat as the main agricultural crop and merely expanded their land holdings instead of adopting new and better production techniques. This "cultural conservatism" was combined with continued population growth (which meant marginally declining returns to land that generated Malthusian pressures), exogenous shocks (the hessian fly, war), ${ }^{2}$ and chronic

\footnotetext{
1 Altman supports the quantitative assertion but disputes the interpretation. Using net farm income for the census year of 1851, he showed that French-Canadian farms were poorer than English-Canadian farms by a sizeable margin. He confirmed the relative poverty of the French-Canadians even though he emphasized noncultural factors, such as access to urban markets, to explain the differences. However, his method of computing output differed from that of Lewis and McInnis (1980, 1984), with whom he engaged in debate. In addition, his estimate of income per farm is very sensitive to the definition of what a farm was. In the census of 1851, many areas had more farms than there were families and dwellings, which suggests a data problem. The extensive debates regarding computing outputs and labor inputs with the 1851 census should incite us to be cautious with the results presented by Altman (see notably Armstrong 1984b; Little 1986; Geloso, Hinton, and Kufenko 2017).

2 The hessian fly is a species of fly that lays its eggs in plants. Its larvae feed on wheat sap, and the plant can no longer bear grain. The fly first proliferated in the United States at the end of the eighteenth century, and it gradually migrated northward to Canada where, by 1805, it was causing important crop failures. It continued to be a problem for Lower Canadian farmers as late as the early 1830s
} 
instability of foreign (British) demand for agricultural goods produced in Canada.

As a result of the combination of these factors, Ouellet and Hamelin (1962, pp. 41-42) speak of declining agricultural outputwhich, given that 80 percent of the population was involved in agricultural work, meant a clear reduction in living standards. In later work (1966, 1980), Ouellet emphasized that falling prices indicated falling living standards, which for him explained the "decline in rural incomes after 1815” (1980, p. 121). McCallum (1980, pp. 4-5) argued that "reports of malnutrition, hunger and even starvation" confirmed the agricultural crisis (for which the decline of wheat production was sufficient proof) and the return to "subsistence agriculture." This view still holds much sway, as can be observed in schoolbooks and popular history books such as Quebec History for Dummies (Bédard 2013, chap. 7) that still present the agricultural crisis as an era of falling living standards that sets the stage for the political rebellions of the late 1830 s.

This viewpoint has been criticized by many in the broadly defined revisionist camp. While this group is less unified in terms of interpretation than the traditionalists are, its members agree on some points. Most of them reject the idea of cultural conservatism that depicts the French-Canadians as insensitive to markets (Lewis and McInnis 1980, 1984; Armstrong 1984a; Courville 1980, 1990, 2008; Paquet and Wallot 2007). They also tend to reject the idea that growth was negative. They either point to slow growth (McInnis 1982 ) or to a crisis that was confined to the 1830s (Courville 1990, 2008). Like geographer Serge Courville (1980, p. 221), one of the earliest revisionists, they tend to agree that "nothing [. . . ] sustains the existence of an agricultural crisis in Lower Canada" and that there is more evidence in favor of economic growth.

For example, Geloso and Kufenko (2015) found that the "Malthusian" equilibrium mechanisms often underlined by the traditionalists were absent during the period from 1760 to 1858, which they argue is strong evidence against the contention of negative economic growth. Using estimates of real wealth growth based on probate records, Paquet and Wallot (2007, p. 471) found an uneven but positive pattern of growth from the 1790 s to the $1830 \mathrm{~s}$

(Jones 1942, p. 141). As for military conflicts, the colony was invaded in 1812 by the Americans and, in 1837-38, was subject to political uprisings that led to several military confrontations in the greater Montreal area, the most agriculturally prosperous region (Laporte 2004). 
(from 18 percent growth on Montreal's north shore to 51 percent growth on Quebec City's south shore). However, the representability of probate records as a measure of economic growth has been heavily questioned (Morin 1981), and much of the remaining revisionist literature has been provided by cliometricians using econometric methods that have been looked down upon by historians who question the quality of the data used (Dechêne 1986; Igartua 1985).

\section{Using Free Banking and the Equation of Exchange to Resolve the Dispute}

Although the debate between the traditionalist and revisionist views has been at a standstill, most of the discussion has taken place with scant reference to economic theory even though the debate is basically about economics. Though there are a few exceptionsnotably Paquet and Wallot (2007), Altman (1998), and Lewis and McInnis $(1980 ; 1984)$ - this absence has allowed the stalemate to persist.

Economic theory can be used to rule out certain possibilities in the presence of low-quality data. For example, limited quantitative and qualitative evidence can be used to establish reasonable assumptions regarding constraints faced by actors in any given market, and as such rule out certain possible developments. ${ }^{3}$ We can use a similar approach for Lower Canada using the rise of free banking and the equation of exchange to seriously question the possibility of negative economic growth. To understand our theoretical reasoning, it is necessary to explain briefly the monetary history of Lower Canada before 1850.

Prior to 1815, Lower Canada's money supply was largely composed of various denominations of American, Spanish, Portuguese, Dutch, English, and French (pre- and postrevolutionary) coins (McIvor 1958; McCullough 1984). Thus, the colony's money supply was largely composed of specie. There were some bills of exchange against merchants (Paquet and Wallot 1983, pp. 475-76),

\footnotetext{
${ }^{3}$ Such a strategy was notably used by Joel Mokyr (1983) in his economic history of Ireland from 1800 to 1850 . The belief generally held was that Ireland's great famine resulted in large part from a Malthusian adjustment mechanism following decades of fast population growth that the country could not sustain. Mokyr presented a fleshed-out understanding of a Malthusian economy and argued that many conditions and outcomes that were expected with such a model were absent. His conclusion was guided by robust logical construction, and it has withstood rigorous empirical testing as new datasets have become available (Kelly and Ó Gráda 2015; Beck Goodspeed 2016).
} 
but they had a limited circulation as a result of doubts over redemption. ${ }^{4}$ Overall, the money supply prior to that point was more or less constant in per capita terms. While colonists complained frequently of a shortage of money, economic historian Angela Redish (1984) has argued that it was really a scarcity of quality coins and that the "hard" money supply was more or less constant in per capita terms (Chapman 1832, pp. 52-53; unknown 1833, p. 149; Martin 1839; Martin 1834, p. 275). ${ }^{5}$

However, with the emergence of free banking (and competitive money issue) in Canada, specie began to loss in importance. In 1817, the Bank of Montreal (which still exists today) managed to establish itself, and by 1822, it had obtained a charter from the colonial legislature (Breckenridge 1894). ${ }^{6}$ Thereafter, banks proliferated in all the colonies and their notes circulated widely. In 1822, there were four banks in Canada as opposed to fourteen in 1850, and the total amount of the notes in circulation surged from $£^{265,625}$ to $£ 2,389,839$, an increase of $£ 0.33$ to $£ 0.96$ per capita (McCullough 1984, pp. 115, 117, 158, 182). ${ }^{7}$ Most banks were in Lower Canada, where the supply of bank notes relative to the population tripled from 1822 to 1850 (see figure 1, where each of the money stocks is indexed to its 1822 starting point). And this is a conservative estimate, as there were many unchartered banks issuing substantial quantities of bank notes. ${ }^{8}$ This rapid and pronounced expansion was

${ }^{4}$ Later, when banknotes emerged, merchant-issued bills of exchange commanded much less favor (Kianieff 2004, p. 413).

5 The coins that circulated up to the 1830s were clipped and worn out, and when good-quality coins circulated, they did so at a premium. Redish (1984) argued that in Canada's multicoin standard with numerous fixed rates between the media of exchange, Gresham's law would materialize and cause overvalued coins to drive out undervalued coins (bad money driving out good money). While the British frequently modified the rates of exchange between the different currencies, the outcome Redish describes is consistent with a difference between the de jure rates and the intrinsic rates (Selgin 1996; Mundell 1998).

6 There were attempts to establish banks in 1792 and 1808, but they failed (Stevenson 1899).

${ }^{7} 1850$ is selected as the endpoint because of the Free Banking Act of 1850, which tightened many regulations. However, most historians and economists agree that growth had started to pick up in Canada by then.

${ }^{8}$ For instance, the smallest of the three cities of the colony, Trois-Rivières, had an unchartered bank, Hart's bank, which issued significant quantities of notes that circulated widely in the inner regions of that district (Trois-Rivières 2009, pp. 4849). In 1838, a prominent landlord of the Joliette area printed a series of bilingual banknotes in very small denominations (fifteen pence; half a dollar). More importantly, he issued those notes in the brief window when convertibility was 
largely unregulated and, as a result, was thus supported by the demand to hold these notes.

Indeed, regulations were light, as the most important ones were that only the directors of a bank were subject to joint liability (shareholders had limited liability), notes smaller than $\$ 1$ (five shillings) could not be issued, usury laws capped interest rates at 6 percent, and debt-to-equity ratios of 75 percent had to be maintained (Breckenridge 1894, p. 470). Beyond that, there were few restrictions, and the system resembled the often-discussed Scottish free banking system (White 1984). Most importantly, with no restrictions on branching, branch networks became common (Schuler 1992, p. 80). From early on, banks would accept the notes of their competitors as payment, bilaterally clearing their balances with competitors once a week, while discounts on notes rarely exceeded 1 percent prior to the 1840 s and largely disappeared after the 1840s thanks to improved transportation (Schuler 1992, p. 82).

Figure 1. Banknotes and total money in circulation and population in Lower Canada $(1822=1)$ on a logarithmic scale

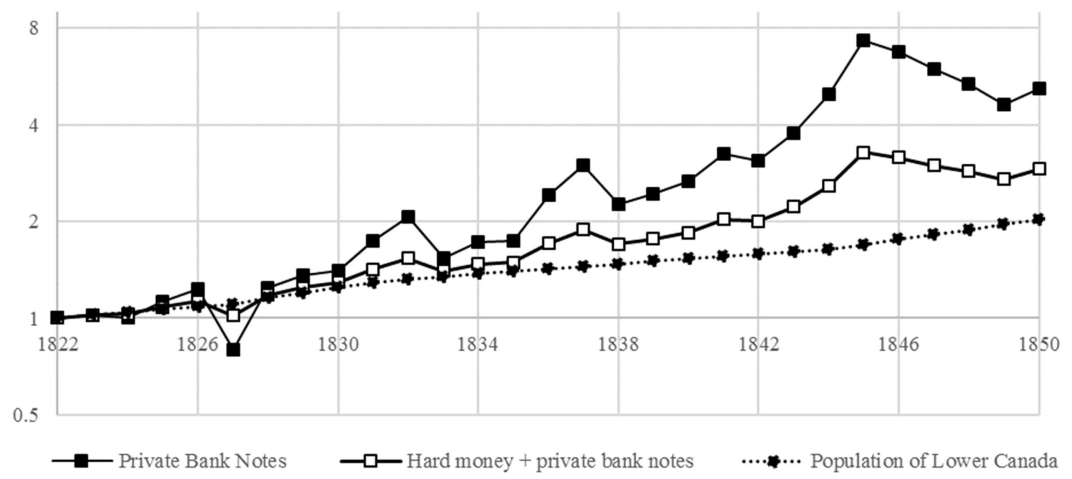

Notes: The population estimates for Lower Canada are drawn from Geloso and Kufenko (2015). The paper money estimates come from McCullough (1984, pp. 11517, 158-59, 182-83). The estimate for hard money comes from Martin (1834, p. 169), who estimated the supply of currency in 1830 at $£ 500,000$. We assumed, as contemporary sources seem to have believed, that this supply was constant in per capita terms. Chapman (1832, pp. 52-53) estimated a much lower quantity of $£, 340,000$ in coins. It is unclear whether Chapman believed this quantity to be constant in per capita terms or constant in absolute terms. If the latter, the evolution of hard money plus private notes would fall between the black-squares series and the white-squares series.

suspended (May 1837 to May 1838) while promising to redeem them against hard currency (Robert 1971, pp. 120-21). We must also add the issue of privately produced tokens (Cross 2015; Russell 1996) that enjoyed wide circulation within the colony, especially during the 1830 s. 
The general consensus in the literature is that free banking was, at the very least, not detrimental to economic growth (Rockoff 1974; Whaples 1995; Jaremski and Rousseau 2013). The best-case scenario is that it helped economic growth (Ager and Spargoli 2013; Selgin and White 1987, 1994) because private banknotes would have financed private investments. In a free banking system, bank notes are not fiat money; rather, they are claims against a bank's assets. As such, notes exchanged are transferable credits that can supplant a large share of cash holdings and expand the scope for private intermediation (Lastrapes and Selgin 2012). ${ }^{9}$ These notes economize on idle specie reserves so that more savings are intermediated through the banking sector to finance private loans and investments.

This economizing on idle specie reserves would have been important in an economy like Lower Canada's, where early nineteenth-century capital markets are often presented as "imperfect." Households are assumed to be unable to access savings from third parties to finance their investments (or provide their savings to other investors) and, as such, their savings largely consisted of accumulated specie reserves (Lewis 2001). The emergence of banks to take deposits and issue private banknotes that are claims against their assets lessened this "imperfect" feature of capital markets. By marshaling more idle specie into intermediation, banknotes allow the greater sophistication and deepening of the financial sector in order to finance productive investments (Selgin 1988, pp. 21-23; Bagehot 1873, pp. 82-85).

The case of Scottish free banking provides a good illustration where, as Adam Smith pointed out, the rise of the free bank replaced a "very expensive instrument of commerce" (i.e., hard money) with "one much less costly" (i.e., redeemable banknotes) ([1776] 1904, p. II.2.26). With Scottish bank reserves of hard money equal to less than 2 percent of banks' demand liabilities, most of Scotland's money holdings served to finance lending for productive investments (Lastrapes and Selgin 2012, p. 392). During its era of free banking, this lending permitted Scotland's economic growth to outpace England's (Cameron 1967, p. 94; White 1984). While far from the

\footnotetext{
9 McCullough (1984, pp. 86-87) gives the example of a $£ 1,000$ promissory note (IOU) to a merchant (i.e., the bank would lend to this merchant). The merchant's account would then be credited for the amount of the loan minus interest collected (at 6 percent over three months, this meant $£_{14.79)}$, and withdrawn in the bank's own notes. The $f_{14.79}$ difference was the bank's profit, to which must be added the value of any notes remaining in circulation after the loan was repaid.
} 
levels observed in Scotland, reserve ratios in Lower Canada fell rapidly, which suggests a similar story. ${ }^{10}$ In 1824, the Bank of Montreal reported a reserve ratio of 54 percent (Armstrong 1984a, p. 97). By 1850, this ratio had fallen to 20.6 percent (Homans 1851, pp. 44-45), and there were years such as 1837 when it fell as low as 17 percent (Armstrong 1984a, p. 97). Contemporary sources confirm this trend when they point out that the population saw coins (especially small denominations) as an inconvenience and often tried to get rid of those they acquired by trading them for bank notes (unknown 1833, pp. 145-46).

The confidence in banknotes and the substantial reduction in the ratio of specie reserves to total liabilities suggest that Lower Canada's money holdings were more productively engaged as a result of the emergence of banks_as in the Scottish case. The proliferation of private banknotes is also indicative of financial deepening (Fry 1988; King and Levine 1993; Levine 1997; Rousseau and Sylla 2005). As the nascent banking system of Lower Canada was able to increase the public's confidence in its banknotes, wide credit networks emerged, suggesting an increased provision of financial services that reached a wider range of individuals. Evidence regarding the expansion of credit networks supports such a contention, as debt per capita increased tenfold in the Montreal area and more than sixfold in the Quebec area from 1792 to 1796 and from 1830 to 1835 even as net household wealth increased by somewhere around 18 percent to 51 percent (Paquet and Wallot 2007, p. 478).

This financial deepening did generate beneficial effects, as it permitted investments in new sectors of economic activity. Courville (1990) points to the rapid emergence of light industries (e.g., carding and fulling mills, saw mills, tanneries, distilleries) in rural areas across Lower Canada, which suggests the beginning of industrialization in the colony. One industry in which large investments were made was the wood products industry (Lower 1973). As that industry's role in economic activity increased, Lower Canada became a net importer of agricultural produce-imports that came largely from the neighboring colony of Upper Canada (modern-day Ontario) and the United States (McInnis 1992) and that were financed by the growing importance of wood-related products in the economy. Deeper credit markets contributed to a gradual shift away from an agriculture-

${ }^{10}$ It is worth pointing out that the first bankers of Lower Canada were Scots who imported numerous features of Scottish free banking into Canada (Bordo, Redish, and Rockoff 2015, p. 224). 
intensive economy since they served to finance the investments in emerging sectors.

In a similar vein, the rapid rise in the supply of private banknotes while the hard money supply remained more or less constant in per capita terms should be considered in relation to the equation of exchange $(M V=P Y) .{ }^{11}$ Banks are indifferent as to the form of credit demand (either checking deposits or banknotes) (Selgin 1988, pp. 111-13). However, holding prices constant, a bank cannot systematically overissue credit beyond its customers' willingness to hold deposits and/or banknotes (White 1999, pp. 53-64; Selgin 1988, p. 39). Otherwise, it will suffer from reserve drain as its notes are redeemed. If, in such an unregulated system, one sees an expansion of the money supply, it means either that banks have acquired more wealth, or that the demand for real cash holdings has increased. According to the equation of exchange $(M V=P Y)$, an increase in $M$ in such a monetary system when $P$ is constant means that either $V$ has fallen or $Y$ has increased. In an unregulated monetary system, an increase in the money supply while prices and velocity are stable rules out the possibility of negative economic growth.

In the case of Lower Canada, the price level was not stable: it was falling. There are three existing price indices for Lower Canada, and all suggest that prices fell rapidly from 1815 to 1820 and then, although there is some volatility, followed a milder downward trend until 1850 (see figure 2). ${ }^{12}$ That this downward trend took place while the money supply was increasing (see figure 1, earlier) weakens the case for negative economic growth. Given that we know the average rate of change in $P$ and $M$ for the period from 1822 to 1850, we can generate different scenarios of changes in $V$ to measure changes in $Y$, as illustrated in table $1 .{ }^{13}$ For that period, the money supply increased on average by 4.24 percent every year. In the same period, the three price indices available suggest average price changes of -0.84 percent (Paquet and Wallot 2007), -0.48 percent (Geloso forthcoming), and 0.46 percent (Ouellet, Hamelin, and Chabot 1982).

\footnotetext{
11 That equation suggests that, if the level of production and the velocity of the circulation of money (i.e., the number of times that money changes hands) remain, changes in price levels correspond to changes in the money supply.

12 The three indices are provided by Paquet and Wallot (2007); Ouellet, Hamelin, and Chabot (1982); and Geloso (forthcoming). The first two rely heavily or entirely on agricultural goods and do not use weights in constructing the baskets. The latter includes a wider array of goods and uses weights for each subcomponent.

${ }^{13}$ We thank an anonymous referee for this very helpful suggestion.
} 
In the scenario where we unrealistically assume no change in velocity, the average annual growth rate for output per capita would have stood somewhere between 1.23 percent and 2.53 percent depending on the price index used. However, constant velocity is unlikely to have been the case, especially since the growth rates that emerge are well above estimates for the nineteenth century, even for the United States (Lindert and Williamson 2016; Bolt and Van Zanden 2014). ${ }^{14}$

Switching to a more plausible scenario in which velocity fell on average by 1 percent per year (implying a 24.5 percent reduction in velocity over this twenty-eight-year period), the range of growth is between 0.23 percent and 1.53 percent per annum. These rates are closer to the 0.4 percent to 0.9 percent per annum found by Paquet and Wallot (2007) when they estimated increases in living standards from the 1790 s to the 1830 s. In a scenario where $V$ falls by 2 percent per year (which amounts to a 43.2 percent reduction in 28 years), the increase in $Y$ relative to the population varies between -0.77 percent and 0.53 percent per year. In this scenario, it should be pointed out that the low range of -0.77 percent is achieved with the price index generated by Ouellet, Hamelin, and Chabot (1982), which uses a limited number of agricultural goods. With the more robust price series provided by Geloso (forthcoming), which has more nonagricultural goods, the increase in $Y$ relative to the population is 0.17 percent per year. Moreover, the estimate of the total money supply (see notes to figure 1) used the highest estimate of the metallic money supply in circulation. As a result, we designed table 1 to make our case as conservative as possible. ${ }^{15}$ Given these elements, the position that living standards were falling is tenuous.

\footnotetext{
14 Long-term declines in velocity are not unheard of. Friedman and Schwartz ([1963] 2008) pointed out that the growth of demand for money in developing economies outstripped-for a time-the growth of real income, which meant that there was a secular trend whereby the velocity of money dropped. Later, Jonung (1978) and Bordo and Jonung $(1981,1990)$ showed similar reductions in velocity.

15 With the Chapman (1832, pp. 52-53) estimates for coins in circulation in the scenario where $V$ falls by 2 percent every year, the growth in $Y$ relative to the population stands between -0.28 percent and 1.02 percent, with the Geloso (forthcoming) price index suggesting a 0.66 percent increase.
} 
Figure 2. Price level in Lower Canada, the United States, and the United Kingdom, 1815-1850 (1815 = 1)

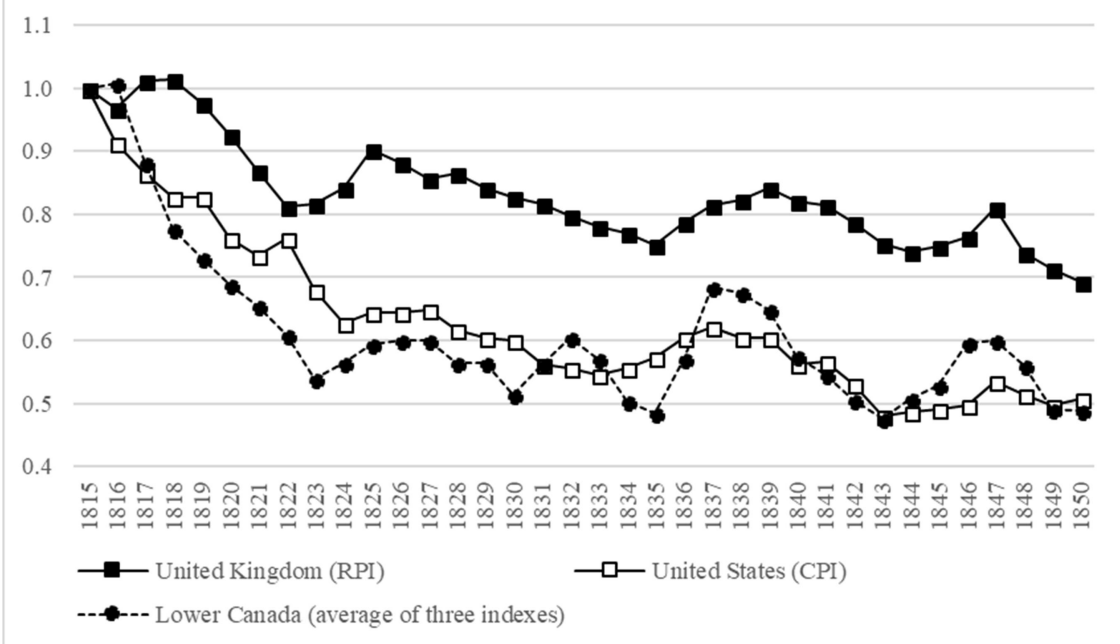

Notes: The price indices used here are those that were publicly accessible for the United States and the United Kingdom. We used them to ensure easy replicability. However, for those who would like the results with other price indices, such as those of McCusker (1993) and Margo (2000) for the United States or Clark (2005) and Broadberry et al. (2015) for the United Kingdom, we did use them and they yielded similar situations. The data for the United States and the United Kingdom were collected from MeasuringWorth.com (consulted January 7, 2015). For Canada, see the text above.

Table 1. Alternative growth scenarios in Lower Canada, 1822-1850, depending on the price index used and the change in velocity (average annual rate of change in components of equation of exchange)

Zero velocity change with Geloso

Zero velocity change with Paquet and Wallot

Zero velocity change with Ouellet et al.

$-1 \%$ velocity change with Geloso

$-1 \%$ velocity change with Paquet and Wallot

$-1 \%$ velocity change with Ouellet et al.

$-2 \%$ velocity change with Geloso

$-2 \%$ velocity change with Paquet and Wallot

$-2 \%$ velocity change with Ouellet et al.

\begin{tabular}{rr} 
Y & Y/Pop \\
$(\%)$ & $(\%)$ \\
\hline 4.72 & 2.17 \\
5.08 & 2.53 \\
3.78 & 1.23 \\
3.72 & 1.17 \\
4.08 & 1.53 \\
2.78 & 0.23 \\
2.72 & 0.17 \\
3.08 & 0.53 \\
1.78 & -0.77 \\
\hline
\end{tabular}

Source: See figures 1 and 2.

Note: The change in $M$ stood at 4.24 percent annually from 1822 to 1850 , while the different changes in $P$ were -0.84 percent (Paquet and Wallot 2007), -0.46 percent (Geloso forthcoming), and 0.48 percent (Ouellet, Hamelin, and Chabot 1982). 


\section{Other Evidence in Favor of the Revisionist Approach}

The portrait drawn with the rise of banking and the equation of exchange is also consistent with other important macroeconomic changes in the economy of Lower Canada. The fall in prices observed in Lower Canada, especially from 1815 to 1835, is similar to the fall observed elsewhere following the end of the Napoleonic Wars, which caused a generalized fall in price levels across countries (Hickernell 1939; Gayer, Rostow, and Schwartz 1959; Mokyr and Savin 1976; McCusker 1993). The war of 1812 to 1815, during which Lower Canada was invaded by the United States, was especially disruptive on the supply side of the economy.

The end of this prolonged period of war would have allowed the supply of goods to expand, as was observed elsewhere (Abel 1980; Lewis 1978; Lana-Berasain 2011), which would have brought prices down. It also should be pointed out that this positive supply shock would militate against the traditionalist emphasis on falling prices as evidence of falling living standards. As Joseph Davis (2004, 2006) observed thanks to his construction of an industrial production index for the United States covering the era from 1790 to 1915, there is a weak correlation between prices and output, suggesting a smoother business cycle than generally believed. ${ }^{16}$ Given the changes in the money supply and prices underlined previously, Canada's situation may have similarities to the situation Davis found for America.

More important, two elements from international trade data reinforce the argument made earlier with the use of the equation of exchange. The first relates to imports per capita. Although an imperfect measure, the study of the value of imports per capita has allowed economic historians such as Julian Gwyn (1998, pp. 160-76) to evaluate the general trend of living standards in Nova Scotia from 1832 to 1872. American economic historians such as Marc Egnal (1975) and John McCusker and Russell Menard (1991) have also used imports in the prerevolutionary American colonies to evaluate the trend in living standards on the grounds that a rising colonial standard of living created a "demand for greater quantities of refined

16 Using industrial production measures, Davis (2004) found that the 1837 and 1873 recessions were in fact very mild in spite of pronounced reductions in prices. In a subsequent article (2006), he pointed out that the dominant chronology of recessions and expansions, which was based on price movements, overstated the volatility of the business cycle. Using his own index of the physical volume of industrial production, Davis found that eight recessions identified using the pricebased measure did not exist. 
imports of all types" (McCusker and Menard 1991, p. 280), and thus imports act as an "imperfect proxy for the rate of expansion of the entire economy" (p. 277). It is on the basis of this idea that an increase in the total volume of trade (which generally indicates higher living standards) can be approximated (in trend only) through one of the variables of the trade balance. As such, figure 3 shows that imports per capita, adjusted for inflation, increased substantially in 1815-20 and 1845-50.

The second element relates to the trade balance. Throughout the period from 1815 to 1850 , the balance of trade between Canada and England was negative (see figure 4) and the data for trade with the United States suggest the same (Redish 1984, p. 726). Thus, it seems clear that the Canadians were shipping their coins abroad to acquire foreign goods (goods such as capital goods or labor-intensive goods, which are scarce in land-abundant frontier economies). ${ }^{17}$ However, maintaining a constant trade deficit (as seen in figure 3) requires net capital inflows to finance it. If the banks of Lower Canada were willing to conserve diminishing reserve ratios (which they were, as indicated earlier), they must have seen the investments made (their assets) become more valuable. The active presence of the Lower Canadian banks in foreign markets suggests that they were exporting IOUs to American and British investors-notably in the lumber and shipbuilding sectors (Lower 1973). ${ }^{18}$ Aubry (1970, pp. 124-65) also underlines a series of capital-intensive projects, such as canals, toll bridges, turnpikes, and railways, meant to facilitate trade within the colony that must be added to those in the lumber and shipbuilding industries. If foreigners were willing to finance the growing level of imports of the inhabitants of Lower Canada, they must have believed that the IOUs they were getting were worth it-which is indicative of growth.

\footnotetext{
${ }^{17}$ See Walton and Rockoff (2005, p. 81) for a discussion of that point.

18 More than half of the first shareholders of the Bank of Montreal were from Boston or New York, and most of the bank's capital was from outside of Canada (Denison 1965, pp. 13, 88).
} 
Figure 3. Imports per capita in Lower Canada (in 1762 constant prices)

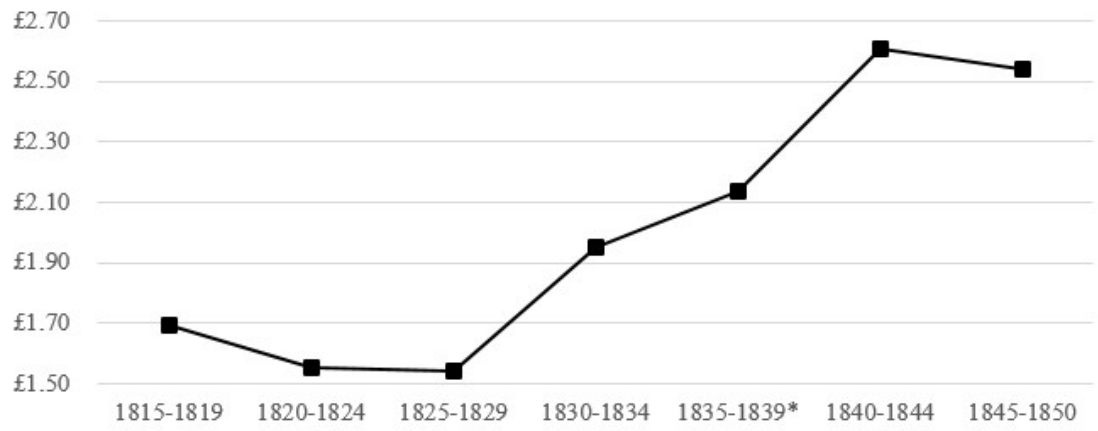

Source: Vallières and Desloges (2008) for imports per capita and Paquet and Wallot (2007) for the price deflator.

Note: * indicates that the year 1836 was missing in the Vallières and Desloges data set.

Figure 4. Balance of trade of Lower Canada, 1815-50 (in 1762 constant prices)

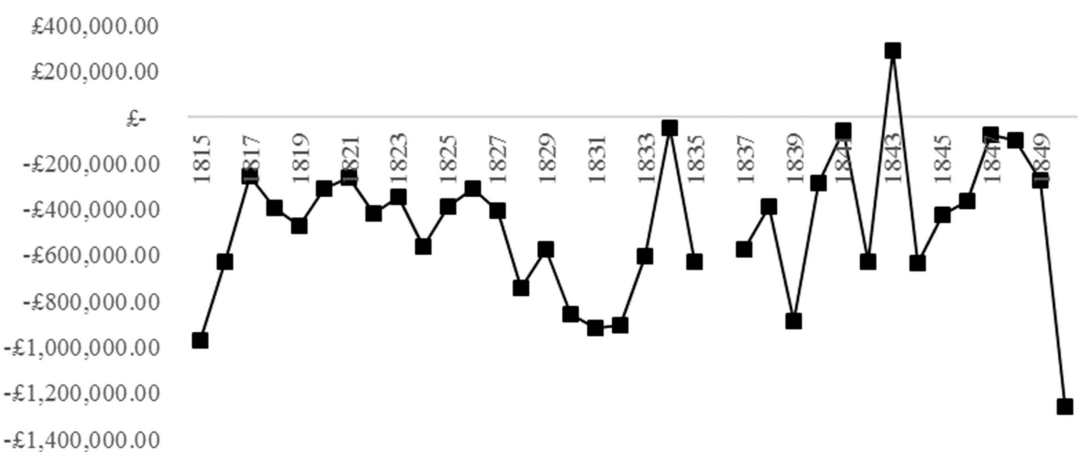

Source: Vallières and Desloges (2008).

Two other changes point in the same direction as the international trade evidence. The first is notably provided by Geloso and Kufenko (2015), who assembled mortality statistics and found a substantial decline in the crude mortality rate during the nineteenth centurywhich stood in stark contrast to the constant increase up to the end of the eighteenth century. While the nineteenth-century reduction in mortality is by no means sufficient to eliminate the increase of the eighteenth century, the direction of the trend suggests some form of improvement in living standards. When we combine the crude mortality rates with the infant mortality rates from Gentil (2009) that cover everything from the mid-1660s to 1779 and those of Vallières 
et al. (2008) that cover 1771 to 1870 (see figure 5), one can observe a clear, albeit modest, improvement in living standards during the nineteenth century.

The second piece of evidence relates to urbanization. There were three urban centers in the colony: Quebec City, Montreal, and TroisRivières-all founded in the seventeenth century. Together, these three cities comprised more than 20 percent of the colonial population during the eighteenth century. All other areas were far behind-no parish came close to having 1,000 inhabitants (Ouellet 1980; Courville 1990, pp. 15, 20, 24). However, at the end of the eighteenth century and especially after 1815, villages began to appear throughout the colony. By 1851, there were 306 villages in the seigneurial portions of Lower Canada, up from 210 in 1831 and 53 in 1815 (Courville 1990, p. 34). Labeling the rise of these villages as "proto-urbanization" (Courville 1987, p. 239) is appropriate, as they constituted the cores of future towns and contained numerous light industries.

Taken alone, the cities and towns saw their share of total population grow from 11.04 percent to 12.85 percent from 1815 to 1851 (Courville 1987, p. 244). However, after adding the village populations of Canada, these figures surge to 17.01 percent of the population to 23.63 percent (Courville 1990, p. 95). This proportion concerns only the seigneurial urban populations (over 80 percent of the colony) divided by the total population of the colony, which assumes that nonseigneurial areas were entirely rural-but they were not. Thus, these figures provide a conservative estimate of the share of urban population; a better estimate is derived in the appendix to this paper.

This growth in urban population is impossible to reconcile with modern growth theory. Increased urbanization is a sign of the breakdown of Malthusian population pressures which, by definition, suggests positive economic growth (Becker and Murphy 1999). Cities promote specialization and human capital investments and thus, "increasing returns from specialization would raise per capita incomes as population grew and are likely to be far more important than diminishing returns in resource-constrained sectors" (Becker and Murphy 1999, p. 146). 


\section{Figure 5. Mortality and infant mortality (per 1,000) in Lower Canada, 1688-1851 (ten-year moving average)}

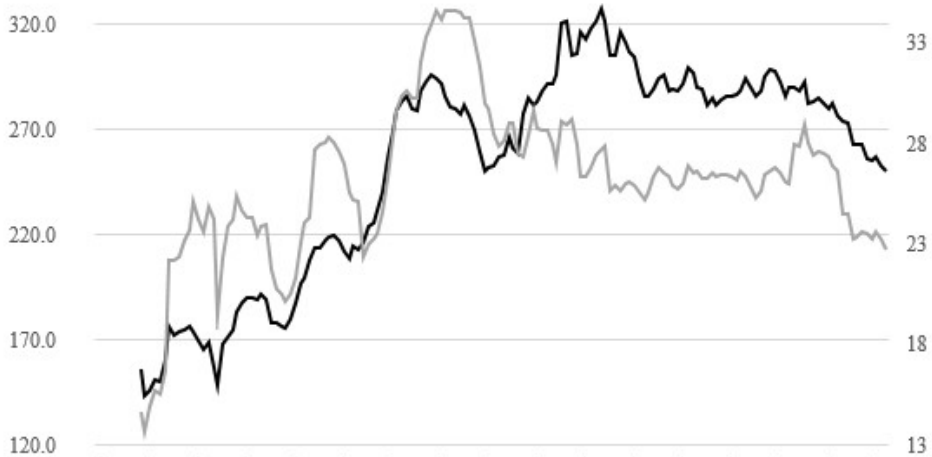

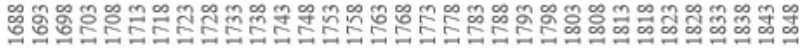

10 per. Mov. Avg. (Infant Mortality Rate (Left Axis))

10 per. Mov. Avg. (Crude Mortality Rate (Right Axis))

Source: Infant mortality quotients from 1688 to 1771 come from Gentil (2009). Infant mortality rates after 1771 come from Vallières et al. (2008). Crude mortality rates come from Geloso and Kufenko (2015).

Note: Gentil computes the infant mortality quotient, which is the number of dead infants over the number of children in the same age group, while Vallières's mortality rate is dead infants over births. The differences are subtle and important for demographers, but they are not relevant here. The two datasets overlap for a few years (1771 to 1779) and they are at similar levels, so they can be linked for the purposes of our article.

\section{Conclusion}

In this paper, we have argued that it is highly unlikely for economic growth to have been negative in Lower Canada from 1815 to 1850. We have used three tools to make our argument. The first relates to the rise of free banking and private bank notes, which allowed money holdings to be diverted for productive investments. The second relates to the theoretical apparatus of the equation of exchange. The emerging banks of Lower Canada were able to convince the area's inhabitants of the reliability of their bank notes, which circulated widely and in rapidly increasing numbers. This rapid expansion of the money supply at a time when the price level was trending downward suggests that, unless there was a substantial decline in velocity over the twenty-eight-year period from 1822 to 1850, negative growth was highly unlikely. The third tool relates to a series of indicators that support the contention that growth was positive. The rising level of imports per capita while the trade deficit remained constant suggests that foreigners were willing to accept Canadian IOUs (indicating a net capital inflow). This situation was combined with the modest 
reversal of the long-term trend of rising mortality rates as well as rising rates of urbanization-two factors whose evolution is inconsistent with the idea of negative growth.

However, we have been careful in this article to avoid stating anything about the pace of growth. The discussion surrounding the equation of exchange suggests modest rates of growth, which would be below those experienced by the United States or by the other Canadian colonies, such as Upper Canada (modern-day Ontario). ${ }^{19}$ Nonetheless, arguing about the pace of growth is not the same as arguing about the possibility of growth, and the case for negative growth seems highly implausible at best. If there were headwinds from other real factors, the rise of the banking sector in Lower Canada provided tailwinds that aided economic growth.

Future research should be oriented toward generating growth rates for Lower Canada in order to extend the results of this paper. Meanwhile, the approach developed here should serve as a guide to what was likely and what was unlikely, helping not only scholars involved in debates about Canadian economic history but also scholars in other fields who want to establish plausible scenarios for historical growth. ${ }^{20}$ Given the richness of price-history data (especially in recent years, thanks to resources such as the AllenUnger data set and the Global Price and Income History Group) and the evidence provided by numismatists with regard to monetary history, the method used in this paper could be an easy step forward when little is known with respect to output.

\section{References}

Abel, Wilhelm. 1980. Agricultural Fluctuations in Europe: From the Thirteenth to the Twentieth Centuries. Oxford: Methuen.

Ager, Philipp, and Fabrizio Spargoli. 2013. Bank Deregulation, Competition and Economic Growth: The US Free Banking Experience. Amsterdam: Tinbergen Institute.

Altman, Morris. 1998. "Land Tenure, Ethnicity, and the Condition of Agricultural Income and Productivity in Mid-Nineteenth-Century Quebec." Agricultural History, 72(4): 708-62.

Armstrong, Robert. 1984a. Structure and Change: An Economic History of Quebec. Toronto: Gage.

\footnotetext{
${ }_{19}$ Slower growth would be consistent with the idea that significant gaps between Lower Canada and other areas would have formed up to 1851 (Egnal 1996; McInnis 1992).

${ }^{20}$ Riley and McCusker (1983) used a similar approach in the case of France from 1650 to 1788 , but to answer a different question from ours.
} 
Armstrong, Robert. 1984b. "The Efficiency of Quebec Farmers in 1851." Social History/Histoire Sociale, 17(33): 149-63.

Aubry, François. 1970. "Indicators of Economic Growth for Lower Canada, 1760_ 1850." Master's thesis, Department of Economics at the University of Ottawa.

Bagehot, Walter. 1873. Lombard Street: A Description of the Money Market, 3rd ed. London: Henry S. King.

Beck Goodspeed, Tyler. 2016. Famine and Finance: Credit and the Great Famine of Ireland. London: Palgrave Macmillan.

Becker, Gary, and Kevin Murphy. 1999. "Population and Economic Growth." American Economic Review, 89(2):145-49.

Bédard, Éric. 2013. Quebec History for Dummies. Mississauga, ON: Wiley \& Sons.

Bolt, Jutta, and Jan Luiten van Zanden. 2014. "The Maddison Project: Collaborative Research on Historical National Accounts." Economic History Review, 67(3): 627-51.

Bordo, Michael David, and Lars Jonung. 1981. "The Long Run Behavior of the Income Velocity of Money in Five Advanced Countries, 1870-1975: An Institutional Approach." Economic Inquiry, 19(1): 96-116.

Bordo, Michael D., and Lars Jonung. 1990. "The Long-Run Behavior of Velocity: The Institutional Approach Revisited.” Journal of Policy Modeling, 12(2): 165-97.

Bordo, Michael D., Angela Redish, and Hugh Rockoff. 2015. "Why Didn't Canada Have a Banking Crisis in 2008 (or in 1930, or 1907, or . . .)?" Economic History Review, 68(1): 218-43.

Breckenridge, Roeliff Morton. 1894. The Canadian Banking System, 1817-1890. New York: American Economic Association.

Broadberry, Stephen, Bruce Campbell, Alexander Klein, Mark Overton, and Bas van Leeuwen. 2015. British Economic Growth, 1270-1870. Cambridge: Cambridge University Press.

Buckley, Kenneth. 1958. "The Role of Staple Industries in Canada's Economic Development." Journal of Economic History, 18(4): 439-50.

Cameron, Rondo. 1967. Banking in the Early Stages of Industrialization. New York: Oxford University Press.

Chapman, Henry Samuel. 1832. Thoughts on the Money and Exchanges of Lower Canada. Montreal: Montreal Gazette Office.

Clark, Gregory. 2005. "The Condition of the Working Class in England, 12092004." Journal of Political Economy, 113(6): 1307-40.

Courville, Serge. 1980. "La crise agricole du Bas-Canada, éléments d'une réflexion géographique." Cahiers de géographie du Québec, 24(62): 193-223.

Courville, Serge. 1987. "Un monde rural en mutation: le Bas-Canada dans la première moitié du XIXe siècle." Histoire sociale/Social History, 20(40): 237-58.

Courville, Serge. 1990. Entre Ville et Campagne: l'essor du village dans les seigneuries du Bas-Canada. Québec: Presses de l'Université Laval.

Courville, Serge. 2008. Quebec: A Historical Geography. Vancouver: University of British Columbia Press.

Cross, W. K. 2015. A Charlton Standard Catalogue: Canadian Colonial Tokens. Toronto: Charlton Press.

Davis, Joseph. 2004. “An Annual Index of US Industrial Production, 1790-1915." Quarterly Journal of Economics, 119(4): 1177-1215.

Davis, Joseph. 2006. "An Improved Annual Chronology of US Business Cycles since the 1790s." Journal of Economic History, 66(1): 103-21. 
Dechêne, Louise. 1986. "Observations sur l'agriculture du Bas-Canada au début du XIXe siècle.” In Évolution et Éclatement du Monde Rural, France-Québec XVII-XXè siècles, edited by Joseph Goy and Jean-Pierre Wallot, 189-202. Montreal: Presses de l'Université de Montréal.

Denison, Merrill. 1965. La Première Banque au Canada, vols. 1 and 2. Toronto: McClelland and Stewart.

Egnal, Marc. 1975. "The Economic Development of the Thirteen Continental Colonies, 1720 to 1775." William and Mary Quarterly, 32(2): 191-222.

Egnal, Marc. 1996. Divergent Paths: How Culture and Institutions Have Shaped North American Growth. Oxford: Oxford University Press.

Friedman, Milton, and Anna Schwartz. (1963) 2008. A Monetary History of the United States, 1867-1960. Princeton, NJ: Princeton University Press.

Fry, Maxwell. 1988. Money, Interest, and Banking in Economic Development. Baltimore: Johns Hopkins University Press.

Gayer, Arthur, Walt Rostow, and Anna Schwartz. 1953. The Growth and Fluctuation of the British Economy, 1790-1850: An Historical, Statistical, and Theoretical Study of Britain's Economic Development, 2 vols. Oxford: Clarendon Press.

Geloso, Vincent, and Vadim Kufenko. 2015. "Malthusian Pressures: Empirical Evidence from a Frontier Economy." Journal of Population Research, 32(3-4): 263-83.

Geloso, Vincent, Michael Hinton, and Vadim Kufenko. 2017. “The Equally 'Bad' French and English Farmers of Quebec: New TFP Measures from the 1831 Census." Historical Methods: A Journal of Quantitative and Interdisciplinary History, 50(3): 170-89.

Geloso, Vincent,. Forthcoming. "A Price Index for Canada, 1688 to 1850." Canadian Journal of Economics.

Gentil, Marilyn. 2009. "Les niveaux et les facteurs déterminants de la mortalité infantile en Nouvelle-France et au début du régime anglais (1621-1779).” PhD thesis, Department of Demography, Université de Montréal.

Gwyn, Julian. 1998. Excessive Expectations: Maritime Commerce \& the Economic Development of Nova Scotia, 1740-1870. Montreal: McGill-Queen's University Press.

Hickernell, Warren. 1939. "An Index of 10 Commodities, Monthly, 1815-60 in the New York City Wholesale Markets." Journal of the American Statistical Association, 34(205): 71-78.

Homans, J. Smith. 1851. The Bankers' Magazine and Statistical Register. Boston: WM Crosby and HP Nichols.

Igartua, José. 1985. "Le Québec de Pangloss: Structure and Change: An Economic History of Quebec." Revue d'bistoire de l'Amérique française, 39(2): 253-61.

Jaremski, Matthew, and Peter Rousseau. 2013. "Banks, Free Banks, and US Economic Growth.” Economic Inquiry, 51(2): 1603-21.

Jones, Robert Leslie. 1942. "French-Canadian Agriculture in the St. Lawrence Valley, 1815-1850.” Agricultural History, 16(3): 137-48.

Jonung, Lars. 1978. "The Long-Run Demand for Money: A Wicksellian Approach." Scandinavian Journal of Economics, 80(2): 216-30.

Kelly, Morgan, and Cormac Ó’Gráda. 2015. "Why Ireland Starved after Three Decades: The Great Famine in Cross-Section Reconsidered." Irish Economic and Social History, 42(1): 53-61. 
Kianieff, Muharem. 2004. "Private Banknotes in Canada from 1867 (and before) to 1950." Queen's Law Journal, 3: 400-48.

King, Robert, and Ross Levine. 1993. "Finance, Entrepreneurship and Growth." Journal of Monetary Economics, 32(3): 513-42.

Lana-Berasain, José-Miguel. 2011. "Dealing with Deflation in Turbulent Times: Agricultural Markets and Rural Management in Southern Navarre (Spain), 1817-1833." Histoire et mesure, 26(1): 75-104.

Laporte, Gilles. 2004. Patriotes et Loyaux: Leadership régional et mobilisation politique en 1837 et 1838. Montreal: Septentrion.

Lastrapes, William, and George Selgin. 2012. "Banknotes and Economic Growth." Scottish Journal of Political Economy, 59(4): 390-418.

Levine, Ross. 1997. "Financial Development and Economic Growth: Views and Agenda." Journal of Economic Literature, 35(2): 688-726.

Lewis, Frank. 2001. "Farm Settlement with Imperfect Capital Markets: A LifeCycle Application to Upper Canada, 1826-1851." Canadian Journal of Economics, 34(1): 174-95.

Lewis, Frank, and Marvin McInnis. 1980. "The Efficiency of the French-Canadian Farmer in the Nineteenth Century." Journal of Economic History, 40(3): 497-514.

Lewis, Frank, and Marvin McInnis. 1984. "Agricultural Output and Efficiency in Lower Canada, 1851." Research in Economic History, 9: 45-87.

Lewis, Frank, and Malcolm Charles Urquhart. 1999. "Growth and the Standard of Living in a Pioneer Economy: Upper Canada, 1826 to 1851." William and Mary Quarterly, 56(1): 151-81.

Lewis, W. A. 1978. Growth and Fluctuations, 1870-1913. London: George Allen and Unwin.

Lindert, Peter, and Jeffrey Williamson. 2016. Unequal Gains: American Growth and Inequality since 1700. Princeton, NJ: Princeton University Press.

Little, Jack. 1986. "Agricultural Progress in Canada East/Quebec: Problems in Measuring Relative Productivity during the Grain-Dairy Transition Period." Social History/Histoire Sociale, 18(36): 425-31.

Lower, Arthur. 1973. Great Britain's Woodyard: British America and the Timber Trade, 1763-1867. Montreal: McGill-Queen’s University Press.

Margo, Robert. 2000. Wages \& Labor Markets in the United States, 1820-1860. Chicago: National Bureau of Economic Research \& University of Chicago Press.

Martin, Richard Montgomery. 1834. History of the British Colonies, vol. 3. London: James Cochrane.

Martin, Richard Montgomery. 1839. Statistics of the Colonies of the British Empire in the West Indies, South America, North America, Asia, Austral-Asia, Africa and Europe. London: W. H. Allen.

McCalla, Douglas. 1985. "The Internal Economy of Upper Canada: New Evidence on Agricultural Marketing before 1850.” Agricultural History, 59(3): 397-416.

McCalla, Douglas. 1993. Planting the Province: The Economic History of Upper Canada, 1784-1870. Toronto: Government of Ontario and University of Toronto Press.

McCalla, Douglas. 2008. "Des Pays d'en Haut au Haut Canada: la formation d'une économie de colonisation." Histoire, économie \& société, 27(4): 87-107.

McCallum, John. 1980. Unequal Beginnings: Agriculture and Economic Development in Quebec and Ontario until 1870. Toronto: University of Toronto Press. 
McCullough, A. B. 1984. Money and Exchange in Canada to 1900. Toronto: Dundurn.

McCusker, John. 1993. How Much Is That in Real Money? A Historical Price Index for Use as a Deflator of Money Values in the Economy of the United States. Worcester, MA: American Antiquarian Society.

McCusker, John, and Russell Menard. 1991. The Economy of British America, 16071789. Chapel Hill, NC: University of North Carolina Press.

McInnis, Marvin. 1982. "A Reconsideration of the State of Agriculture in Lower Canada in the First Half of the Nineteenth Century." Canadian Papers in Rural History, 3: 9-49.

McInnis, Marvin. 1992. Perspectives on Ontario Agriculture. Gananoque, Ontario: Langdale Press.

McIvor, Craig. 1958. Canadian Monetary, Banking and Fiscal Development. Toronto: Macmillan.

Mokyr, Joel. 1983. Why Ireland Starved: A Quantitative and Analytical History of the Irish Economy, 1800-1850. London: George Allen \& Unwin.

Mokyr, Joel, and N. Eugene Savin. 1976. "Stagflation in Historical Perspective: The Napoleonic Wars Revisited.” Research in Economic History, 1: 198-259.

Morin, Yvan. 1981. "La représentativité de l'inventaire après décès: L'étude d'un cas: Québec au début du XIXe siècle." Revue d'histoire de l'Amérique française, 34(4): 515-33.

Mundell, Robert. 1998. "Uses and Abuses of Gresham's Law in the History of Money." Zagreb Journal of Economics, 2(2): 3-38.

Ouellet, Fernand. 1966. Histoire économique et sociale du Québec, 1760 à 1850. Ottawa: Édition Fides.

Ouellet, Fernand.1972. Éléments d’histoire sociale du Bas-Canada. Montreal: Hurtubise $\mathrm{HMH}$.

Ouellet, Fernand. 1980. Lower Canada, 1791-1840: Social Change and Nationalism. Toronto: McClelland and Stewart Limited.

Ouellet, Fernand, and Jean Hamelin. 1962. "La crise agricole dans le Bas-Canada (1802-1837)." Études rurales, 7(1): 36-57.

Ouellet, Fernand, Jean Hamelin, and Richard Chabot. 1982. "Les prix agricoles dans les villes et les campagnes du Québec d'avant 1850: aperçus quantitatifs." Histoire Sociale/Social History, 15(29): 83-128.

Paquet, Gilles, and Jean-Pierre Wallot. 2007. Un Québec Moderne, 1760-1840: Essai d'histoire économique et social. Montreal: Éditions Hurtubise HMH.

Paquet, Gilles, and Jean-Pierre Wallot. 1983. "Le système financier bas-canadien au tournant du XIXe siècle." L'Actualité économique, 59(3): 456-513.Redish, Angela. 1984. "Why Was Specie Scarce in Colonial Economies? An Analysis of the Canadian Currency, 1796-1830." Journal of Economic History, 44(3): 713-28.

Riley, James, and John McCusker. 1983. "Money Supply, Economic Growth, and the Quantity Theory of Money: France, 1650-1788." Explorations in Economic History, 20(3): 274-93.

Robert, J. C. 1971. "L'activité économique de Barthélemy Joliette et la Fondation du Village d'Industrie (Joliette), 1822-1850." Master's thesis, Department of History, University of Montreal.

Rockoff, Hugh. 1974. "The Free Banking Era: A Reexaminiation.” Journal of Money, Credit and Banking, 6(2): 141-67.

Rousseau, Peter, and Richard Sylla. 2005. "Emerging Financial Markets and Early US Growth.” Explorations in Economic History, 42(1): 1-26. 
Russell, Peter. 1996. "New Brunswick's First Copper Coinages.” Acadiensis, 25(2): 105-16.

Russell, Peter. 2012. How Agriculture Made Canada: Farming in the Nineteenth Century. Montreal: McGill-Queen's University Press.

Schuler, Kurt. 1992. "Free Banking in Canada." In Experience of Free Banking, edited by Kevin Dowd, 79-92. New York: Routledge.

Séguin, Maurice. 1970. La Nation Canadienne et l'Agriculture (1760-1850): Essai d'Histoire Économique. Montreal: Éditions Boréal Express.

Selgin, George. 1988. The Theory of Free Banking: Money Supply under Competitive Note Issue. London: Rowman \& Littlefield.

Selgin, George. 1996. "Salvaging Gresham's Law: The Good, the Bad, and the Illegal." Journal of Money, Credit and Banking, 28(4): 637-49.

Selgin, George, and Lawrence White. 1987. "The Evolution of a Free Banking System.” Economic Inquiry, 25(3): 439-57.

Selgin, George, and Lawrence White. 1994. "How Would the Invisible Hand Handle Money?" Journal of Economic Literature, 32(4): 1718-49.

Shortt, Adam. (1900) 1986. "The History of Canadian Currency, Banking and Exchange." In Adam Shortt's History of Canadian Currency and Banking, 16001880, edited by Nancy Leaman, 201-7. Toronto: Canadian Bankers Association.

Smith, Adam. (1776) 1904. An Inquiry into the Nature and Causes of the Wealth of Nations. London: Methuen.

Smith, Vera. 1936. The Rationale of Central Banking and the Free Banking Alternative. Indianapolis, IN: Liberty Fund.

Stevenson, James. 1899. The Currency of Canada after the Capitulation. Literary and Historical Society of Quebec.

Trois-Rivières. 2009. Rencontrer Trois-Rivières: 375 ans d'bistoire et de culture. TroisRivières, QC: Éditions d'Art le Sabord.

Unknown. 1833. Present State of the Canadas: Containing Practical and Statistical Information Respecting the Climate, Soil, Produce, Agriculture, Trade, Currency, Banking \&c., of Upper and Lower Canada, Useful for the Emigrant, Merchant and Tourist. London: G. Herbert.

Vallières, Marc, and Yvon Desloges. 2008. "Les échanges commerciaux de la colonie laurentienne avec la Grande-Bretagne, 1760-1850: L'exemple des importations de produits textiles et métallurgiques." Revue d'bistoire de l'Amérique française, 61(3-4): 425-67.

Vallières, Marc, Yvon Desloges, Fernand Harvey, Andrée Héroux, Réginald Auger, Sophie-Laurence Lamontagne, and André Charbonneau. 2008. Histoire de Québec et de sa région, Tome 1: Des origines à 1791. Quebec: Presses de l'Université Laval.

Walton, Gary, and Hugh Rockoff. 2005. History of the American Economy, 10th ed. Mason, OH: South-Western.

Whaples, Robert. 1995. "Where Is There Consensus among American Economic Historians? The Results of a Survey on Forty Propositions." Journal of Economic History, 55(1): 139-54.

White, Lawrence. 1984. Free Banking in Britain: Theory, Experience, and Debate, 18001845. London: Cambridge University Press.

White, Lawrence. 1999. The Theory of Monetary Institutions. Oxford: Blackwell. 